\title{
Memory, Marketing and Economic Performances in Usa Symphony Orchestras and Opera
} Houses

\author{
Angela Besana \\ Annamaria Esposito
}

Department of Business, Law, Economics and Consumer Behavior, IULM - Milan Italy

\begin{abstract}
When resources are scarce at crisis times and when competition is intense with other creative supplies, USA symphony orchestras and opera houses memorize and perform their repertoires (or repertories), so that seasons are crucially bundled between tradition and innovation. Since the beginning of the latest financial and real crisis (2007), USA classical music has seen different levels of funding from the federal government and businesses have encouraged more nonconventional programming (Pompe, Tamburri, 2016; Turbide, Laurin, 2009; Ravanas, 2008; Rushton, 2008; Turrini, 2006; Smith, 2007). On one side, fundraisers have stressed bundles (contemporary music with tradition) to sponsors; on the other side, marketing officers have emphasized the repertoire memory to audiences who constantly love Traviata, Boheme and Don Giovanni with echo of famous regisseurs, scenographers, etc. This is quite the same worldwide (Cancellieri, Turini, 2016). Fundraising and marketing affect economic performances of classical music, also thanks to social media and networks. Consumers have access to information about ticketing, rehearsals, present and past performances, etc. Art organizations strive to manage communication via social media to create brand values. Social media support both fundraising and marketing, as they mediate to sponsors and audiences: values, advocacy, videos and photos of the repertoire and nonconventional programming, which continually increase trustworthy relationships and nurture memories. This paper investigates 200 USA symphony orchestras and opera houses according to repertoires, revenues, expenses and gains in 2008 and 2015. With cluster analysis, three profiles emerge with different strategies, performances and emphasis on memory or innovation.
\end{abstract}

Keywords: Memory, Marketing and Economic Performances in Usa Symphony Orchestras and Opera Houses

\section{Introduction}

When resources are scarce at crisis times and when competition is intense with other creative supplies, repertoire is a very important asset for USA symphony orchestras and opera houses. Since the beginning of the latest financial and real crisis (2007), USA classical music has different levels of funding from the federal government and businesses have encouraged more nonconventional programming (Pompe, Tamburri, 2016; Turbide, Laurin, 2009; Ravanas, 2008; Rushton, 2008; Turrini, 2006; Smith, 2007). While public supports for contemporary performances are substantially weakening, fundraisers of symphony orchestras and opera houses have, as a matter of fact, stressed bundles (contemporary music with tradition) to sponsors, while marketing officers of the same classical music have stressed the repertoire memory to audiences who constantly love Traviata, Boheme and Don Giovanni, Mozart's, Beethoven's and Tchaikovsky's concerts together with the echo of famous interpreters, musicians, singers, directors, set designers, scenographers and other creative 'voices and hands'.

Repertoire is here meant as well-known and constantly-seasoned performances, also remembering famous bundles of star-interpreters, conductors, directors and other creative roles in opera and symphony. Theaters are supposed to balance past and present (Ross, 2017), though experimentation can be difficult to audiences as they have to be educated about it. Above all, today's audiences rarely subscribe. They prefer spot experiences and novelty may be excluded from the spot experience. Their risk aversion for surprise and 'revolution' does result in their looking for repertoire and their being disinclined for subscriptions, which include the past and the present they do not know about. 
Audiences prefer standard repertoire (Tamburri, Munn, Pompe, 2015; Pompe, Tamburri, Munn, 2011). Repertoire consists of Beethoven, Mozart, Verdi, Puccini and other few composers, whose music is regularly performed. Repertoire memory also refers to recalling (revivals) of famous and in-house productions, with stars. A fixed assortment of works for the age of compositions and versioning with top musicians and the other creative roles.

The League of American Orchestras and operabase.com collect data on audiences' preferences, engagement (from communities to visitors) and composers, who are constantly present in season. If the League of American orchestras count an audience of more than 20 million in 2015, statista accounts on the number of people who visited symphony concerts and operas within the last 12 months in the United States recorded 14.49 million in spring 2008 and 17.58 million in spring 2015 (https://www.statista.com/statistics/227502/symphony-concert-opera-etc-visitors-usa last accessed on the $24^{\text {th }}$ of July 2017). This is an evidence of a growing audience, which can include communities, subcribers (though drastically fallen during the latest financial and real crisis), single donors (increasing during the latest financial and real crisis), who profit by the fringe benefit of a free performance and tourists, who are today paid attention, if it is considered that 25 percent of income derives from services like parking, rentals, presentation activities and other contents of the latest bundle 'plan your own experience' (Guachalla, 2012; Boerner, Moser, Jobst, 2011; Woosnam, McElroy, Van Winkle, 2009). This audience can be well-educated. Nevertheless, this audience's memory relies on some famous composers before or just at the beginning of the twentieth century.

If program decisions are influenced by various factors, repertoire memory has been leading the planning of USA symphony orchestras and opera houses for decades. According to the latest repertoire report of the League in 2013, only 4.1 percent of seasons were contemporary (Ross, 2017). The propensity for standard repertoire has been confirmed since 2008, when the real and financial crisis hit availability of resources, from money to in-kind, together with keen competition with other entertainment, falling donations, subscriptions and international tours. Since 2008 seasons have been, as a matter of fact, enriched thanks to well-managed approaches to edutainment, community engagement, technological innovation like appealing social media, for the attraction of communities and non-communities (tourists). Repertoire has remained a gainful factor, while experimentation and contemporary music are still encouraging new directions in the art and appreciation by sponsors and public administrations (from government to local authorities, looking for native and contemporary music). Repertoire memory does not exclude innovation, if increasing subsidies, government support, competition and education increase experimentation (Cameron, 2016; Ravanas, 2007 and 2008; Borgonovi, 2006; Bennett, 2005).

Audiences do not resist temptation of contemporary music, when they are well-educated. At the same time, they do not resist revival of operas and concerts, which have been absent in seasons for decades. They need education in all hypothesis of repertoire, 'recovered' repertoire (revivals) and innovation. The USA classical music is therefore committed to Education and Community Engagement Programs, they are fully dedicating resources with detailed reports and analysis to. They work with schools and non-schools (health and wellness organizations, senior service providers, organizations focused on racial diversity and inclusion, organizations working to address poverty, homelessness, domestic violence and abuse in their communities, etc.). This trend confirms attention for different audiences, their empowerment and engagement, their being ready for repertoire or native music (for senior audiences) and contemporary or non-classical series (millennials).

As a matter o fact, this duality repertoire/experimentation is strategically nurtured by the duality marketing/fundraising. Marketing is supporting the promotion of standard and non-standard repertoires. Who is gaining the highest earned income, this opera house or symphony orchestra is profiting by a gain in 2015. Repertoire memory is leading revenues at the box office, though fundraising is pivotal for the most gainful organizations.

Marketing and fundraising do not necessarily generate a trade-off or separation of resources and goals (Besana, 2012; Song, Yi, 2011; Borner, Moser, Obst, 2011; Turbide, Laurin, 2009; Borgonovi, 2006, Bussell, Forbes, 2006). For Education and Community Engagement Programs, Marketing Experts are segmenting audiences (Kemp, Poole, 2016; Radbourne, Johanson, Glow, White, 2009; Turbide, Laurin, Lapierre, Morrisette, 2008; Johnson, Garbarino, 2001), while Fundraisers (of the same classical music) are targeting grant-makers like community and family foundations for their advocacy to local communities empowerment and sensibility for these programs, to be funded.

Marketing and fundraising can differently affect economic performances of the USA classical music (Voss, Voss, Yair, Lega, 2016; Bussell, Forbes, 2006; Bennett, 2005). On the one hand, these strategies can have different objectives but complimentary financial results, on the other hand, thanks to social media and networks, consumers have access to 
information about ticketing, giving options and their benefits, rehearsals, live and past performances, downloads, etc. Social media support both fundraising and marketing, as they mediate to sponsors and audiences: values, advocacy, videos and photos of the repertoires and nonconventional programming, which continually increase trustworthy relationships and nurture memories. Strategies can be offline and online developed with common goals, with different impacts on revenue diversification and gains of the USA classical music (Kemp, Poole, 2016; Jeannotte, Duxbury, 2015; Pierotti, Risaliti, Cestari, 2014; Hong, 2014). The ultimate goal, marketing officers and fundraisers join their efforts for, refers to an entertaining and educating creative supply of repertoire and non-repertoire, increase and diversification of audiences and stakeholders, financial soundness.

This paper investigates 200 symphony orchestras and opera houses according to their repertoires, revenues, expenses and gains (or losses) in 2008 and 2015. Thanks to cluster analysis, three profiles will emerge with different strategies, performances, emphasis on memory or innovation and social media. Contributions are the prevailing revenue source and the Fundraiser profile shows the highest gain both in 2008 and 2015. Marketing affects program service revenues, 43 percent for the most crowded cluster in 2008 and 39 percent for 31 organizations with a gain of 1.33 percent in 2015. In these clusters with the highest percentage of program service revenue, repertoire is a leading asset, both for community engagement and any other visitors.

\section{Fundraising and marketing of the USA classical music: social media si può? More than a prologo!}

As above-mentioned, fundraising and marketing are essential in the USA classical music. Strategic scenario has changed considerably over the last decade. After draft and encouraging experimentation, technology, the Internet and the WEB 2.0 have really reshaped the way audiences and organizations interact, communicate and join for the common goal of the survival of music. The USA classical music is more than in a prologo-phase. Digital communication has granted new opportunities and challenges both for organizations and their stakeholders for more than a decade (Lewicki, 2016; Kornum, Mülbacher, 2013; Liang, Turban, 2011; Neslin, Shakar, 2009). For-profit and not-for-profit organizations, cultural and creative organizations, they are all profiting by the digital society and the classical music 'hits high notes' with targets as regards both marketing and fundraising.

On the one hand, thanks to social media and social networks, stakeholders have access to large amount of information about organizations and the creative supply, they can be educated about. On the other hand, symphony orchestras and opera houses strive to manage marketing and fundraising via social media to create customer and brand value. Social media, as internet-based application Web 2.0, allows the creation and exchange of User Generated Content (Kaplan, Haenlein, 2010) that are leading a transformation in the management of relationships with customers (Moretti, Tuan, 2014; Kietzmann et al., 2011): contents are not simply delivered to audiences and friends, but they are also discussed, further promoted to new audiences, ranked in comparison with benchmark initiatives (education and community programs), so that they gain new willingness-to-pay and new willingness-to-donate.

Orchestras and opera houses, in order to grasp the attention of customers, friends and boost online B2C sales/donations, they are investing in social media marketing. Social media marketing strategies are designed to offer customer new experiences, and to enhance customer participation and engagement (Corbitt, Thanasankit, Yi, 2003; Brodie et al., 2011; Huang, Benyoucef, 2013; Ceruti, Mazzucchelli, Di Gregorio, 2015). Especially, when experiences can be enhanced with music, videos, downloads, recordings, virtual participation to rehearsals and primas, very next to the stage, offline and online: memory of sounds, voices, music is here playing a key-role and 'repertoire memorabilia' are leading contents in social networks.

Social media marketing strategies allows organizations to hear and talk with prospects and customers, to develop and deepen the relationship with all stakeholders. Marketers are aware that social media marketing can bring organizations near customers, and doing so, generate knowledge and brand values that help to increase revenues, decrease costs and improve efficiency: a content, when it is engraved and recalled on memories (repertoire, above all), it is granting advocacy, willingness and trustworthiness. Consequently, organizations can achieve a greater economic value (Michaelidou et al., 2011; Huang \& Benyoucef, 2013).

As can be understood, social media marketing implies a new way to manage relationships with stakeholders, from audiences to donors, sponsors and grant-makers, and, according to Moretti and Tuan (2014), it can be considered as an evolution of Relationship Marketing concept and practice (Vivek et al., 2012). In s-commerce, customers, audiences and 
philanthropists have to be engaged more and more via appealing, social, and interactive ways in order to build trust, that is a crucial factor in the success of a life-long relation. Trust leads to relationship commitment that is really important in the social media environment, where normally online communities generate conversations and relationships, which are no longer monitored by companies (Mangold, Faulds, 2009; Kim, Park, 2013). For art organizations, online communities are an opportunity to find volunteers, too. In addition, these interactions can affect the very next marketing (Pastore, 2009; Sashi, 2012), making customers to become co-producers and co-creators of the value of the organizations, and finally prosumers. Trustworthy and co-creative relations can evolve in friendships and marketing can be complimentary with fundraising, in order to exploit both willingness-to-pay and the willingness-to-donate

To successfully exploit the potential of social media, organizations need to facilitate collaborative experiences and dialogue, to become part of the conversation and design experiences that deliver tangible value in return for customers' time, attention, endorsement and data (Baird, Parasnis, 2011). Revival of past performances and repertoire can enhance relations. Furthermore, they can integrate the experience with other customer-facing initiatives. Maestros, orchestras and singers' engagement become essential to personalize relationships and cultivate customers' tastes, emotions and advocacy.

Social media marketing managers must strengthen social experiences with time-sensitive offers or discounts that motivate customers to act (Naadem, 2012), and incentives for people to share content with friends to capitalize on the viral benefits a network offers. Regarding social media platforms, Facebook and Twitter are the top choices. But as marketers gain experience with all senses, feelings and skills their arts can affect, their marketing efforts seem to expand across all major social platforms such as Google+, YouTube, linkedin, Pinterest and Instagram. Social media are useful to facilitate prospect and customer transition from the social platform to the organization website and viceversa, and they participate in all stages before and after product or service purchase, before and after donation, before and after experience as a musical tourist, too.

Concluding, in the above depicted scenario, marketers and fundraisers have great opportunities to boost online business, advocacy and willingness-to-pay and to-donate integrating social networks and e-commerce platforms. On the one hand, social media marketing conveys also promotional messages, transforming social media in effective and powerful advertising channels, able to engage, motivate and convince users to seek and share information about products or services, including those relating to their online purchases. Merchandising can be shopped on the main website, after advertising in social networks: this merchandising can concern specific performances. Nevertheless, repertoire and revivals of famous and past performances, they are successfully printed on several gadgets and they are regularly downloaded as trailers, memorabilia and edutainment.

On the other hand, social media marketing is able to solve one of the most important problems which are connected to ecommerce research phase, when user tends to get lost, bored, and often does not finalize the purchase. E-commerce must be an environment, where everything user needs can be found easily. Social media could be the solution transforming ecommerce in social commerce (Stelzner, 2015; Xu, Forman, Kim, Van Ittersum, 2014; Zhou, Zhang, Zimmermann, 2013; Rigby, 2011). Prospect and customers can use the social media platforms on which they spend most of the time to go through all the steps before and after the purchase without never get out of there.

As above depicted, the relationship between social media and classical music is close and full of interesting and engaging ideas, opportunities and promising scenarios. E-commerce, s-commerce and above all, relations can grow with positive impacts on economic performances.

\section{Research Method}

\section{Methodology}

In order to investigate economic performances, 990 forms from the fiscal years 2008 and 2015 are here analyzed with the Internal Revenue Service (IRS), categories 'A69-Symphony Orchestra' and 'A6A-Opera': 100 organizations for each category, from the highest to the lowest total income. These reports can be downloaded from the Guidestar website www.guidestar.org and the main websites of the organizations themselves. The Guidestar website contains 990 forms from nonprofits, such as detailed statements of revenues and expenses and financial statements. The sample adds up to 200 organizations, whose 990 forms were downloadable at www.guidestar.org or at their own websites at the end of 2016. 
As reported in the 990 form glossary revenues of a nonprofit organization in the USA may include: Direct public support: contributions, gifts, grants and bequests received directly from the public. It refers to amounts received from individuals, trusts, corporations, estates, foundations, public charities or raised by an outside professional fundraiser; Government contributions or grants: payments from the Government to a nonprofit organization to further the organization's public programs. Direct public support, Government contributions and grants are summed so that the whole extent of Contributions can be estimated. The other revenue categories are Program service revenues: fees and other monies received by an organization for services rendered.

If contributions and program service revenues constitute more than $90 \%$ of the sample, ancillary revenues derive from Investment income and other revenues. Revenue diversification will be here analyzed as concerns main categories: Contributions with the target of willingness-to-donate and Program Service Revenue with the target of willingness-to-pay. The weight of investment gain and other revenue will also be counted, as it was previously considered that 25 percent of earned income can derive from services like parking, special events (with orchestras, the conductor or/and singers), tours (though diminishing internationally) ... so that the USA classical music target different segments, tourists included.

Expense categories include: Program Service Expense related to marketing and production of the core business; Fundraising expense and Management and general expense, a miscellaneous cost that is not related to the previous accounting lines. According to IRS standards, if the fundraising expense must be separately reported, the marketing or advertising expense can be included in the other expenses. The personnel expense will also be calculated here, in order to appreciate the magnitude of the internal labour intensity of employees (administrative and creative) and their engagement in repertoire and non-repertoire.

Next to the analysis of revenue and expense categories, the (Net) Gain or Loss of the year as the difference - positive or negative - between revenues and costs, it is also here analyzed.

Economic analysis is here connected with the season details for repertoire and non-repertoire. These contents and data can be found in mission statements, annexes of 990Forms, websites, conferences highlights and reports of networks of the USA classical music (orchestra 'facts' of the League of American Orchestras and statistics of www.operabase.com).

First of all, accounting data are entered into Excel and indexed to total revenues - for revenue categories - and total expenses - for expense categories -. Gain or loss is also included in the analysis, indexed to total revenues.

Secondly, these ratios are clustered, in order to obtain meaningful groups with relevant and separating features in 2008 and 2015.

Cluster analysis is the process of dividing a set of observations into a number of groups. In particular, K-means clustering is an iterative follow-the-leader strategy. First, the number of clusters, $k$, must be specified. Then a search algorithm finds $\mathrm{k}$ points in the data, called seeds, that are not close to each other. Each seed is then treated as a cluster center. The routine goes through the points (rows) and assigns each point to the cluster it is closest to. For each cluster, a new cluster center is formed as the means (centroid) of the points currently in the cluster. This process continues with an alternation between assigning points to clusters and recalculating cluster centers until the clusters become stable. Cluster means show the average performances of significant groups.

After having detected significant and the most crowded clusters as concerns economic performances, the content check of repertoire, the most supplied composers and operatic towns in USA, they are all considered in order to connect financial viability with repertoire and non-repertoire. The link is the profiling for prevailing strategies and revenues: if marketing is positively affecting program service revenue, repertoire is supposed to be one main goal of marketing with maximization of the program service revenue; if fundraising is positively affecting revenues, repertoire can be next to experimentation which is supported by courageous and non-cyclic public and private supports and contributions, as a consequence, prevail.

\section{Findings. Ed al vero ispiravasi...}

Apart of outliers and small clusters, the k-means analysis of 2008's data gives evidence of three clusters. The most crowded one shows the highest percentage of program service revenue, 43.26 percent. Table 1 shows percentages of revenue diversification, costs and gains for three most crowded clusters.

Table 1. 2008's average performances of the USA classical music between repertoire and nonrepertoire (percentages) 


\begin{tabular}{|c|c|c|c|}
\hline & \multicolumn{3}{|c|}{$\begin{array}{l}\text { Number of organizations in clusters } \\
\text { Labels }\end{array}$} \\
\hline & $\begin{array}{l}60 \text { organizations } \\
\text { The Marketing Expert for } \\
\text { Repertoire }\end{array}$ & $\begin{array}{l}51 \text { organizations } \\
\text { The Fundraiser with the highest } \\
\text { gain for Repertoire and Non- } \\
\text { Repertoire }\end{array}$ & $\begin{array}{l}44 \text { organizations } \\
\text { Fundraiser }\end{array}$ \\
\hline Contributions/Total Revenues & 47.01 & 69.43 & 55.68 \\
\hline $\begin{array}{l}\text { Program Service Revenue/Total } \\
\text { Revenues }\end{array}$ & 43.26 & 25.19 & 35.80 \\
\hline Investment Gain or Loss/Total Revenues & 4.24 & 3.97 & 2.01 \\
\hline Other Revenue/Total Revenues & 5.48 & 1.39 & 5.49 \\
\hline Program Service Expense/Total Expenses & 82.95 & 74.75 & 64.70 \\
\hline $\begin{array}{l}\text { Management and general Expense/Total } \\
\text { Expenses }\end{array}$ & 11.85 & 17.21 & 28.97 \\
\hline Fundraising Expense/Total Expenses & 5.19 & 8.02 & 6.31 \\
\hline Gain or Loss/Total Revenues & -1.04 & 12.07 & 1.06 \\
\hline Personnel Expense/Total Expenses & 45.81 & 48.55 & 42.69 \\
\hline
\end{tabular}

Source: elaboration with JUMP Software

Contributions are the prevailing revenue for all clusters. The program service revenue is high when repertoire is emphasized by marketing, with the highest sum of program service and management (and general) expenses. The strategy mix does not exclude common goals. For the most crowded cluster with 60 organizations, 10 percent of revenues are investment income and other earnings, too. For all clusters, for more than 40 percent of costs, the personnel expense gives evidence of the effort, in order to provide excellence in production (repertoire, revival of past repertoires, contemporary productions, etc.) and proficiency in marketing and fundraising.

With Metropolitan Opera, the Carnegie Hall, Chicago organizations like Symphony Orchestra, Sinfonietta, Opera Theatre, Lyric Opera, Houston Symphony Society, Pocket Opera in San Francisco, Lyric Opera San Diego, New Mexico Symphony Orchestra, Opera Company of Philadelphia, Saint Louis Symphony Orchestra, San Diego Symphony Orchestra, Boston Youth Symphony Orchestra, etc., the Marketing Expert for Repertoire, shows the highest Program service revenue, other revenue, program service expense, the second highest personnel expense, the lowest fundraising expense and a very modest loss of 1.04 percent, on average. Repertoire is here constantly present for the appreciation of national and international audiences in tourist attractions like New York, Philadelphia, Boston, Saint Louis, etc. Verdi, Mozart and Puccini dominate listings of operabase.com for above-mentioned cities, which are the most operatic ones in the USA: New York in the first place, followed by San Francisco, Chicago, Houston, etc. At a very early beginning, social media and networks supply music and theatrical contents, promotion details for communities and tourists, so that they inspire advocacy and they support marketing of the USA classical music. This confirms results of the audience demographic review of the League of American Orchestras of December 2009 (LAO, Audience Demographic Research Review, December 10th): classical music audiences are adopting digital more rapidly than the overall USA population and marketing directors are suggested to consider how much internet, blogs, downloads and chats are becoming where, how and what of music consumption. Marketing officers seek to better understand digital communities, as they are relatively new in 2008. As a consequence, they enter these communities and monitor comments and feedback.

With 51 organizations, the Fundraiser with the highest gain for repertoire and non-repertoire is affected by the highest contributions, the highest fundraising expense, the highest gain and the lowest program service revenue. Fundraising is connecting this classical music to grant-making foundations, sponsors, donors, local government and other stakeholders, who can deliver grants for community programs. Marketing goals are never separated from fundraising ones. Grants support marketing goals, too. Cincinnati Opera, Dallas (the 16th operatic city) Opera, Delaware Symphony, Kansas City Symphony and Lyric Opera, Los Angeles (the $7^{\text {th }}$ operatic city) Opera, Nashville Symphony and Opera, San Francisco (the second operatic city) Opera, Santa Barbara Symphony, Seattle Opera (the $11^{\text {th }}$ operatic city) are in this cluster included. Social media are here engaging multiple audiences. In 2008, social media and networks represent an opportunity for storytelling of local projects with foundations, local governments and other stakeholders, too. 
With 44 organizations, the Fundraiser is an intermediate profile between the previous clusters. This cluster includes Atlanta Opera, Baltimore Opera Company, Boston Lyiric Opera, California Symphony, El Paso Symphony, Jacksonville Symphony, New Orleans Opera, Portland Maine Symphony, Portland Opera and other organizations whose connections with local communities, governments, sponsors are well-nurtured thanks to social media, where intermediate and final results of projects are meant for emphasis and benchmarking.

In 2015, after the crisis, fundraising is the leading strategy. Program service revenue are not more than 40 percent of revenues. Contributions are more than 50 percent for three significant and most crowded clusters in Table 2.

Table 2. 2015's average performances of the USA classical music between repertoire and nonrepertoire (percentages)

\begin{tabular}{|c|c|c|c|}
\hline & \multicolumn{3}{|c|}{$\begin{array}{l}\text { Number of organizations in clusters } \\
\text { Labels }\end{array}$} \\
\hline & $\begin{array}{l}68 \text { organizations } \\
\text { The Fundraiser }\end{array}$ & \begin{tabular}{|l|}
52 organizations \\
The Fundraiser with the highest \\
gain for Repertoire and Non- \\
Repertoire
\end{tabular} & $\begin{array}{l}31 \text { organizations } \\
\text { The Marketing Expert for } \\
\text { Repertoire }\end{array}$ \\
\hline Contributions/Total Revenues & 56.34 & 64.56 & 54.95 \\
\hline $\begin{array}{l}\text { Program Service Revenue/Total } \\
\text { Revenues }\end{array}$ & 36.43 & 23.82 & 39.86 \\
\hline Investment Gain or Loss/Total Revenues & 2.08 & 10.38 & 0.78 \\
\hline Other Revenue/Total Revenues & 5.13 & 1.22 & 4.39 \\
\hline Program Service Expense/Total Expenses & 74.78 & 80.03 & 74.83 \\
\hline $\begin{array}{l}\text { Management and general Expense/Total } \\
\text { Expenses }\end{array}$ & 17.45 & 12.74 & 23.95 \\
\hline Fundraising Expense/Total Expenses & 7.75 & 7.22 & 1.20 \\
\hline Gain or Loss/Total Revenues & 0.16 & 14.43 & 1.33 \\
\hline Personnel Expense/Total Expenses & 49.38 & 45.52 & 44.88 \\
\hline
\end{tabular}

Source: elaboration with JUMP Software

The fundraiser profile is prevailing with a fundraising expense for more than 7 percent for two clusters. The Marketing Expert, with the highest program service revenue of (only) 39.86 percent, the highest sum of program service and management (and general) expenses, the lowest fundraising expense and the second highest gain of the compared clusters, includes 31 organizations. This cluster is not more the most crowded one as it was for 2008's data. The personnel expense still shows the in-supplied creativity for the whole sample. If social media were in start-up in 2008 , their use evolved and mature in 2015.

In the Marketing Expert cluster (31 organizations), the Carnegie Hall can still be found. Apart of this organization, no other opera house and symphony orchestra of this cluster is in the most operatic cities in the USA. Repertoire is here meant to support communities around the classics, the native music and the tradition, they have grown up for the cultural dialogue with (African American, Hispanic Latino, Asian American, American Indian, ...). At the same time, some mid- and smallsized organizations of this cluster may show 'more freedom to experiment, since audiences are less likely to associate them with tradition and propensity for classics' (Ross, 2017; Yi, 2010; Poon, Lai, 2008). Fundraising is indispensable for more than 50 percent of revenues.

In the Fundraiser with the highest gain (52 organizations), we can find New York, Chicago, San Francisco, Houston and Los Angeles (the most operatic cities in 2015) symphony orchestras and opera houses, whose fundraising is supported not only by the story-telling of social media but also the discussion thanks to social networks of reports, redemption of economic and social performances in local communities, partnerships with foundations and sponsors, special fundraising events. The highest gain of the sample can nurture seasons with repertoire and non-repertoire.

In the most crowded cluster (68 organizations), the Metropolitan Opera is included. Organizations are in big and operatic cities like Boston, San Francisco, Houston, Saint Louis, Milwaukee, Seattle and Boston according to operabase.com. Fundraising is here meant as key-strategy. Program service revenue is still more than 36 percent of all revenues. Social 
media both support discussions, suggestions, dialogues with musicians, singers, conductors, regisseurs, etc. and tell about partnerships, special programs for communities, quarters, citizens and not-citizens.

In comparison with 2008, fundraising became a must in 2015. Marketing can generate revenues, repertoire can be an asset. Nevertheless, ticketing is not solving for the financial soundness of these organizations.

\section{Results and Discussion}

Audiences love repertoire. Nevertheless, paying audiences are not more sufficient for financial soundness of USA symphony orchestras and opera houses (2015). Fundraising has helped the USA classical music out of the crisis and it is today generating revenues more than marketing. Both for the cluster analysis in 2008 and in 2015 (for Fundraisers with the highest gain), when program service revenues are the fewest ones and contributions are the highest ones of the sample, profits are the highest ones, too. The highest program service revenue is combined with the second highest gain in 2015.

Repertoire plays a key-role for recalling of masterpieces, well-known compositions and revivals, which are appreciated by audiences. Marketing officers are fully aware that repertoire memory must be constantly paid attention. At the same time, grant-makers and sponsors are fully aware that they are vital for the survival of tradition and experimentation. Balance between the past and the present would not be possible, if contributions were not available. Marketing officers play in teams with fundraisers, in order to maximize program service revenues and contributions of the USA classical music. The duality marketing/fundraising can be given evidence with separate profiles according to economic performances both in 2008 and 2015 , but this duality must not be magnified.

Social media can support these organizations both for fundraising and marketing goals, though experimentation might be more communicated than in the past. This might be, in order to educate audiences, visitors and any other stakeholders to new tastes. Past and new tastes can generate increasing program service revenues, which could return to 2008's percentages, for more than 40 percent.

Some mission statements (in summary on the first page of 990 forms) of the organizations in the most crowded 2015's cluster can give evidence to this multiple attention and commitment for different audiences and contents, the community issue, the classical series and experimentation: ... to encourage musical excellence in a professional and supportive environment by providing the highest quality orchestra training and performance opportunities... and making its programs accessible to undeserved communities through financial assistance (Boston Youth Symphony); ... the Buffalo Philharmonic Orchestra Society produce symphonic music fro the cultural benefit of the Buffalo, New York area, including artistic education programs for area youth; ... production of symphony performances for the benefit of the local community (Cheyenne Symphony); ... the New Mexico Philharmonic is committed to inspiring audiences of all ages and backgrounds through its artistic excellence, innovative programming and education and community engagement; the mission of Pensacola Opera is to enrich the culture of northwest Florida by producing professional opera performances, educational programs and other opera-related community events for people of all ages, interest and backgrounds; the mission of San Diego Opera is to deliver exceptional vocal performances and exciting, accessible programs to diverse audiences, focusing on community engagement and the transformative power of live performances; the mission of the St Louis Symphony is to enrich people' lives through the power of music; the Seattle Youth Symphony Orchestra provides life changing musical experiences for talented students in the Pacific Northwest, regardless of their financial resources. SYSO students develop their relationship to great music, expand their capacity to self-discipline and focus, learn the value of community and teamwork, and continuously acquire new musical skills with professional artist teachers. SYSO's goal is to transform students' lives by positively shaping the artistic, social, emotional and intellectual development of young people. We will be recognized as a leader in classical music education locally and nationally. Our programs and performance will be celebrated for their innovation and excellence. We will be a model of financial sustainability and we will enjoy generous, committed and broad-based community support. ...

\section{Conclusion}

For more than two decades, community engagement with multiculturalism, digital revolution with information overload, audiences' preferences and segmentation, public and private philanthropy have been evolving in the strategic scenario of 
the USA classical music. Today marketing and fundraising of USA symphony orchestras and opera houses, they both include diversified tactics and strategies: audiences and philanthropists are investigated as for their willingness-to-pay and willingness-to-donate and they are paid attention for their tastes, feelings, visions and engagement. While tourists can represent the frontier of their flexible pricing, social media are levers of all their audiences and stakeholders and they can invite and 'consolidate' younger audiences with flexible subscriptions in comparison with 2008, when the median age of a classical music concertgoer was 49. Economic performances, financial viability and robustness follow, as a consequence and the here investigated sample shows that fundraising is the leading strategy.

As a matter of fact, apart of a price strategy that implies discrimination for segmented audiences and a prevailing taste for repertoire, symphony orchestras and opera houses innovate their communication thanks to social media and these networks may be the very next frontier to educate for nonrepertoire and experimentation, in order to increase the creative bundle and packaging, they regularly supply and they innovate.

The duality marketing/fundraising cannot be thought as a trade-off. Fundraising is supplying resources for both repertoire and nonrepertoire. For spot visitors and for communities, fundraising and marketing are separate in literature and they can give evidence of separate performances as it is in this investigation. Both of them, they work for the same goal.

Considering the period 2008-2015, it can be confirmed that fundraising is evolving with a much more impressive and economic weight than in the past. Nevertheless, as revenue diversification can be more successful than focus on one type of revenue and it is complementary with business diversification, repertoire and nonrepertoire can balance with balancing different marketing and fundraising efforts. Marketing and fundraising do not have, otherwise, to assault newcomers, who often suffer for poor parking and difficulties for tickets change (Rosen 2017). Marketing and fundraising should inspire a gentle mixing with sense and sensibility towards audiences and stakeholders who are targeted with multiple and creative contents.

Revenue management implies the key-consideration fundraising performances can support or compensate marketing ones, especially when marketing suffers of losing subscriptions and increase of spot-sales. Focus on several and multiple stakeholders is the next frontier, where social media can lead the USA classical music.

Research limitations refer to boundaries and small dimension of the sample, which concerns orchestras and opera houses in very different cities in North America: some of them are very big, operatic and tourism destinations, some of them may not be considered as main attractions for leisure tourists. The duality marketing/fundraising can stress economic performances and profile poles. Nevertheless it is the mixing, which must be paid focus on in order to investigate both economic and social impacts. At the same time, the international financial and real crisis was dramatic for USA performing arts both on the demand and the supply side, so that average performances of clusters could be partially compromised by the bias of the general lack of resources for the investigated period (2008-2015).

Managerial implications include that orchestra and opera managers should intensify their focus, much more today than in the past, on new audiences like millennials, tourists, natives and 'social groupings' according to the evidence of social media on the marketing side and international friends, foundations and sponsors with different propensities for supporting repertoire and nonrepertoire on the fundraising side. Today, much more than in the past, the USA classical music should be committed to Education and Community Engagement Programs with dedication of resources, monitoring, analysis and redemption with detailed reports and focus on benchmarks. Above all, managers should continually balance propensities for both past and present music, offline and online marketing and fundraising with a high-lighted focus on the added value of dialogue and participation to creativity.

\section{References}

[1] Baird C.H., Parasnis G., (2011) From social media to social customer relation management. Strategy \& Leadership, 39(5):30-37.

[2] Bennett, R., (2005) Factors Encouraging Competitive Miopia in the Performing Arts Sector: An Empirical Investigation. The Service Industries Journal, 25(3):391-401.

[3] Besana, A., (2012) Alternative Resources: Revenue Diversification in the Not-for-Profit USA Symphony Orchestra. The Journal of Arts Management, Law and Society, 42(2):79-89.

[4] Boerner, S., Moser, V., Jobst, J., (2011) Evaluating cultural industries: investigating visitors' satisfaction in theatres. The Service Industries Journal, 31(6):877-895. 
[5] Borgonovi, F., (2006) Do public grants to American theatres crowd-out private donations?. Public Choice, 126:429-451.

[6] Brodie R.J., Hollebeek L.D., Juric B., Illic A., (2011) Customer engagement: Conceptual Domain, Fundamental Propositions and Implications for Research. Journal of Service Research, 14(3):252-271.

[7] Bussell, H., Forbes, D., (2006) "Friends" Schemes in Arts Marketing. International Journal of Arts Management, 8(2):39-49.

[8] Cameron, S., (2016) Past, present and future: music economics at the crossroads. Journal of Cultural Economics, 40:1-12.

[9] Cancellieri, G., Turrini, A. (2016) The Phantom of Modern Opera: How Economics and Politics Affect the Programmin Strategies of Opera Houses, International Journal of Arts Management, 18(3): 25-36.

[10] Ceruti F., Mazzucchelli A., Di Gregorio A., (2015) E-commerce or s-commmerce? A managerial perspective on online customers engagement. Proceedings of 2015 SIM (Società Italiana di Marketing) Conference, Turin, 2015.

[11] Corbitt B.J., Thanasankit T., Yi H., (2003) Trust and e-commerce: A study of consumer perceptions. Electronic Commerce Research and Applications, 2(3):203-215.

[12] Guachalla, A. (2012) The role of cultural flagships in the perception and experience for tourism and culture. Case study: The Royal Opera House in Covent Garden. European Journal of Tourism Research, 6(1):83-87.

[13] Hong, J., (2014) Data Envelopment Analysis in the Strategic Management of Youth Orchestras, The Journal of Arts Management, Law, and Society, 44(3):181-201.

[14] Huang Z., Benyoucef M., (2013) From e-commerce to social commerce. A close look at design features. Electronic Commerce Research and Applications, 12(4):246-259.

[15] Jeannotte, M.S., Duxbury, N., (2015) Advancing Knowledge through Grassroots Experiments: Connecting Culture and Sustainability, The Journal of Arts Management, Law, and Society, 45(2):84-99.

[16] Johnson, M.S., Garbarino, E., (2001) Customers of Performing Arts Organizations: Are Subscribers Different from Non-Subscribers?. International Journal of Nonprofit and Voluntary Sector Marketing, 6(1):61-72.

[17] Kaplan A.M., Haenlein M., (2010) Users of the world, unite! The challenges and opportunities of social media. Business Horizons, 53(1): 59-68.

[18] Kemp, E., Poole, S.M., (2016) Arts Audiences: establishing a Gateway to Audience Development and Engagement, The Journal of Arts Management, Law and Society, 46(2):53-62.

[19] Kietzmann J.H., Hermkens K., Mccarthy I.P., Silvestre B.S., (2011) Social Media? Get serious! Understanding the functional building blocks of Social Media. Business Horizons, 54(3): 241-251.

[20] Kornum N., Mülbacher H., (2013) Multi-stakeholder virtual dialogue: introduction to the special issue, Journal of Business Research, 66 (9):1460-1464.

[21] League of American Orchestras (2009) Audience Demographic Research Review, last accessed at www.americanorchestras.org in July 2017.

[22] Lewicki M., (2016) E-Shop Offer as a Tool Creating Value for Customer. In: Bilgin, M. H., Danis, H., Demir, E., Can, U., 2016. Business Challenges in Changing Economics Landscape. Eurasian Studies in Business and Economics 2/2:221-230.

[23] Liang T.P., Turban E., (2011) Introduction to the Special Issue Social Commerce: A Research Framework for Social Commerce. International Journal of Electronic Commerce, 16/2:5-14.

[24] Mangold G.W., Faulds D.J., (2009) Social media: The new hybrid element of the promotion mix. Business Horizons, 52:357-365.

[25] Michaelidou N., Siamagka N.T., Christodoulides G., (2011) Usage, barriers and measurement of social media marketing: $A B$ exploratory investigation of small and medium B2B brands. Industrial Marketing Management, 40(1):1153-1159.

[26] Moretti A., Tuan A., (2014) Social Media Marketing and relationship marketing: revolution or evolution? A first step analysis. Sinergie, 93:115-137.

[27] Nadeem W., (2012) Social Customer Relationship Management (SCRM): How Connecting Social Analytics to Business Analytics Enhances Customer Care and Loyalty? International Journal of Business and Social Science, 3(21):88-102.

[28] Neslin S.A., Shakar V., (2009) Key issues in multichannel customer management: Current knowledge and future directions. Journal of Interactive Marketing, 23:70-81. 
[29] Pierotti, M., Risaliti, G., Cestari, G., (2014) Managing IC in an Opera House: the case of La Scala. European Scientific Journal, 10(34):1-22.

[30] Pompe, J., Tamburi, L. (2016) Fiddling in a Vortex: Have American Orchestras Squandered Their Supremacy on the American Cultural Scene?. The Journal of Arts Management, Law and Society, 46(2):63-72.

[31] Pompe, J., Tamburri, L. (2011) Factors that influence programming decisione of US symphony orchestras, Journal of Cultural Economics, 35:167-184.

[32] Poon, J.P.H., Lai, C.A. (2008) Why are Non-profit Performing Arts Organisations Successful in Mid-sized US Cities? Urban Studies, 45(11): 2273-2289.

[33] Radbourne, J., Johanson, K., Glow, H., White, T., (2009) The Audience Experience: Measuring Quality in the Performing Arts, 11(3):16-29.

[34] Ravanas, P., (2007) A Quiet Revolution: The Metropolitan Opera Reinvents Client Relations Management. International Journal of Arts Management, 9(3), 79-87.

[35] Ravanas, P., (2008) Hitting a High Note: The Chicago Symphony Orchestra Reverses a Decade of Decline with New Programs, New Services and New Prices, International Journal of Arts Management, 10(2):68-78

[36] Rigby D., (2011) The Future of Shopping. Harvard Business Review, 89(12):64-75.

[37] Rosen J., (2017) Visions of Orchestras, Symphony, 19-24.

[38] Ross A., (2017) The Greatness Paradox. Symphony, 28-32.

[39] Smith, T., (2007) The Impact of Government Funding on Private Contribution to Nonprofit Performing Arts Organizations. Annals of Public and Cooperative Economics, 78(1):137-160.

[40] Song, S., Yi, D.T. (2011) The fundraising efficiency in US non-profit art organizations: an application of a Bayesian estimation approach using the stochastic frontier production model. Journal of Production Analysis, $35: 171-180$.

[41] Stelzner M.A., (2015) How Marketers are using social media to grow their businesses. Social Media Marketing Industry Report, Social Media Examiner.

[42] Tamburri, L.; Munn, J.; Pompe, J. (2015) Repertoire Conventionality in Major US Symphony Orchestras: Factors Influencing Management's Programmin Choices, Manabgeriale and Decision Econnomics, 36:97-108.

[43] Turbide, J., Laurin, C., (2009) Performance Measurement in the Arts Sector: The Case of the Performing Arts. International Journal of Arts Management, 11(2):56-70.

[44] Turbide, J., Laurin, C., Lapierre, L., Morissette, R., (2008) Financial Crises in the Arts Sector: Is Governance the IIIness or the Cure?. International Journal of Arts Management, 10(2):4- 13.

[45] Turrini, A., (2006) Measuring Audience Addiction to the Arts. International Journal of Arts Management, 8(3):4353.

[46] Vivek S.D., Beatty S.E., Morgan R.M. (2012) Consumer engagement: Exploring customer relationships beyond purchase. Journal of Marketing Theory and Practice, 20, (2):122-146.

[47] Voss, Z.G., Voss G.B., Yair, K., Lega, K. (2016) Orchestra Facts: 2006-2014, last accessed at www.americanorchestras.org in July 2017.

[48] Woosnam, K.M., McElroy, K.E., Van Winkle, C.M., (2009) The Role of Personal Values in Determining Tourist Motivations: An Application to the Winnipeg Fringe Theatre Festival, a Cultural Special Event. Journal of Hospitality Marketing and Management, 18:500-511.

[49] Xu J., Forman C., Kim J.B., Van Ittersum K., (2014) News Media Channels: Complements or Substitutes? Evidence from Mobile Phone Usage. Journal of Marketing, 78(4):97-112.

[50] Yi, D.T. (2010) Determinants of Fundraising Efficiency of Nonprofit Organizations: Evidence from US Public Charitable Organizations. Managerial and Decision Economics, 31:465-475.

[51] Zhou L., Zhang P., Zimmermann H.D., (2013) Social commerce research: an integrated view. Electronic Commerce Research and Applications, 12(2):61-68. 